\title{
Pembuatan Karbol sebagai Desinfektan Lantai
}

\author{
Supandi $^{1 *}$, Pramulani Mulya Lestari ${ }^{1}$ Ani Pahriyani ${ }^{1}$ \\ ${ }^{1}$ Fakultas Farmasi dan Sains, Universitas Muhammadiyah Prof. DR. Hamka, Jakarta, Indonesia \\ *Email korespondensi: supandi@uhamka.ac.id
}

\begin{abstract}
Abstrak
Sehat adalah impian semua manusia, tubuh manusia memiliki pertahanannya sendiri, dengan cara-cara tertentu bagian dari tubuh sudah mampu untuk bertahan dan melawan penyakit.Mencegah suatu penyakit dan penyebarannya dapat dilakukan mulai dari diri sendiri dan lingkungan sebagai sarana untukmengurangi penyebaran penyakit karena mikroorganisme. Untuk menunjang kesehatan maka perlu dilakukan pembekalan kepada ibu-ibu dalam pengenalan kerbersihan dan pelatihan pembuatan karbol. Produk karbol ini dibuat dengan metode sederhana sesuai dengan kemampuan Perumahan Villa Mutiara Gading 3. Pembuatan diawali dengan melarutkan arpus ke dalam cairan $\mathrm{NaOH}$ hingga larut, kemudian tambahkan campuran antara pine oil, teepol dan propilenglikol hingga semua tercampur homogen.Karbol siap digunakan. Produk yang dihasilkan merupakan karbol desinfektan lantai. Karbol yang baik adalah yang dapat membersihkan sekaligus dapat membunuh kuman, tidak licin dan aman digunakan.
\end{abstract}

Kata Kunci: Karbol, PPPM, Desinfektan

\begin{abstract}
Healthy is the dream of all humans, the human body has its own defenses, in certain ways parts of the body are able to survive and fight disease. Preventing a disease and its spread can be done from yourself and the environment as a means to reduce the spread of disease due to microorganisms. To support health, it is necessary to provide supplies to mothers in the introduction of cleaning and carbolic training. This carbolic product is made with a simple method in accordance with the capabilities of Villa Mutiara Gading Housing 3. Making begins with dissolving arpus into $\mathrm{NaOH}$ liquid until it dissolves, then add a mixture of pine oil, teepol and propylenglycol until all are homogeneously mixed. The baseball is ready for use. The product produced is a disinfecting carbolic floor. A good carbol is one that can clean and kill germs, not slippery and safe to use.
\end{abstract}

Keywords: Carbolic Acid, PPPM, Disinfectant

Format Sitasi: Supandi, Lestari, P.M., Pahriyani, A. (2019). Pembuatan Karbol sebagai Desinfektan Lantai. Jurnal Solma, 8(2), 193-200. Doi: https://dx.doi.org/10.29405/solma.v8i2.3183

Diterima: 26 Februari 2019 | Revisi: 27 September 2019 | Dipublikasikan: 21 Oktober 2019 (c) 1 BY
(C) 2019. Oleh authors. Lisensi Jurnal Solma, LPPM-Uhamka, Jakarta. Artikel ini bersifat open access yang didistribusikan di bawah
syarat dan ketentuan Creative Commons Attribution (CC-BY) license. (http://creativecommons.org/licenses/by/4.0/).

\section{PENDAHULUAN}

Sehat adalah impian semua manusia, tubuh manusia memiliki pertahanannya sendiri, dengan cara-cara tertentu bagian dari tubuh sudah mampu untuk bertahan dan melawan penyakit. Tidak semua penyakit memerlukan obat-obatan seperti; batuk, flu, diare dapat disembuhkan dengan menjaga kebersihan, istirahat yang cukup serta makan 
yang bergizi (Oktarini, 2013). Ataupun penyakit-penyakit yang di picu oleh faktor kebersihan seperti malaria, demam berdarah, typus dapat dicegah dengan menjaga kebersihan. Penyakit-penyakit itu muncul karena mudahnya serangga-serangga pembawa penyakit untuk berkembang biak. Serangga seperti lalat, cacing, dan nyamuk juga virus yang dapat menyebabkan penyakit seperti influenza yang mudah tersebar melalui media udara yang tidak sehat (Dewi, Iravati, \& Sarto, 2016).

Mencegah suatu penyakit dan penyebarannya dapat dilakukan mulai dari diri sendiri dan lingkungan sekitar, dirumah misalnya. Sebagian besar aktivitas sehari - hari di rumah dilakukan di lantai sehingga banyak mikroba yang menempel ke permukaan tubuh saat kita sedang bersentuhan langsung dengan lantai yang pada akhirnya dapat menimbulkan penyakit yang selanjutnya dapat dikaitkan dengan penularan berbagai penyakit ataupun penyebaran mikroorganisme. Beberapa penelitian membuktikan bahwa Escherichia coli (E. coli) merupakan salah satu bakteri yang paling sering ditemukan di lantai (Dewi et al., 2016; Listyawati, 2007). Selain itu, Staphylococcus aureus (S. aureus) merupakan salah satu bakteri yang sering ditemukan di berbagai tempat, antara lain: permukaan benda, baju, lantai, tanah, rumah sakit, bahkan pada kulit manusia, dan bersifat patogen bagi manusia (Brooks, Carroll, Butel, \& Morse, 2007).

Kebersihan lantai sering kali dikaitkan dengan kebersihan suatu tempat secara umum. Berbagai cara dapat dilakukan dan diterapkan untuk menjaga kebersihan lantai. Seperti kebiasaan melepas sepatu sebelum masuk ke rumah dapat mengurangi penyebaran mikroorganisme penyebab infeksi mata, perut dan paru-paru (Pohla, 2008). Selain menerapkan kebiasaan-kebiasaan baik tersebut, masyarakat juga dapat menggunakan cairan pembersih lantai yang dapat membersihkan lantai sekaligus membunuh mikroorganisme yang menempel di lantai (Ariani, Setiani, \& Joko, 2015). Produk yang dapat membunuh mikroorganisme di dalam maupun permukaan benda mati adalah disinfektan. Zat ini tidak harus bersifat sporosidal, melainkan sporostatik yaitu dapat menghambat pertumbuhan kuman (Brooks et al., 2007). Zat disinfektan dalam cairan pembersih lantai akan membunuh mikroorganisme yang terdapat di lantai. Mikroorganisme tersebut antara lain adalah Escherichia coli, Pseudomonas aeruginosa, Enterobacter cloacae, Salmonella sp. dan lain-lain (Dewi et al., 2016). Beberapa disinfektan yang biasa digunakan sebagai pembersih lantai adalah lysol (klorofenol dan kresol), karbol (fenol) dan kreolin (Rasmika Dewi Dap, Susi Iravati, 2008). 
Produk-produk karbol untuk cairan pembersih cukup banyak beredar dipasaran yang kebanyakan adalah hasil produksi industri skala besar, sedangkan kebutuhan pemakaian cukup besar baik dalam rumah tangga, peternakan, restoran, perkantoran dll. Selain di produksi pada skala industri pembuatan karbol dapat dilakukan pada skala rumahan dengan menggunakan bahan-bahan yang mudah didapat. Proses pembuatan karbol yang cendrung mudah dan sederhana, memungkinkan masyarakat untuk membuat karbol sendiri baik untuk kebutuhan rumah tangga maupun untuk menunjang perekonomian keluarga.

Pada kegiatan PPPM ini, yang akan menjadi sasaran adalah ibu-ibu di perumahan Villa Mutiara Gading, Babelan, Bekasi Utara, Jawa Barat. Ibu-ibu di perumahan ini umumnya merupakan ibu rumah tangga yang perlu ditingkatkan kreativitasnya untuk dapat mengembangkan potensi diri melalui peningkatan kreativitas di bidang Teknologi Formulasi. Pengabdian ini diharapkan mampu mengembangkan keterampilan ibu-ibu di perumahan tersebut dalam membuat sediaan desinfektan sehingga akan tumbuh jiwa kewirausahaan. Dengan adanya kegiatan ini diharapkan dapat memberikan manfaat untuk pembuatan desinfektan yang dapat dikembangkan lebih lanjut untuk usaha mandiri ataupun pemenuhan kebutuhan rumah tangga.

\section{MASALAH}

Permasalahan kesehatan yang sistemik dan saling berkaitan masih menjadi tantangan tersendiri dalam upaya tercapainya kualitas kesehatan yang baik dan kesejahteraan yang merata bagi seluruh penduduk serta minimnya pengetahuan dan ide masyarakat terhadap pembuatan produk yang dapat digunakan untuk menjaga kebersihan di lingkungan rumah tangga sekaligus dapat meningkatkan perekonomian keluarga membuat kondisi lingkungan perumahan membutuhkan suatu pemikiran transformasi ilmu pengetahuan dan teknologi dengan memanfaatkan potensi yang ada, sehingga membentuk karakter masyarakat khususnya ibu-ibu untuk berdikari tanpa meninggalkan keluarga.

Program ilmu pengetahuan dan teknologi yang ditawarkan berupa peningkatan pengetahuan dan pelatihan pembuatan karbol secara mandiri yang diarahkan untuk meningkatkan kemauan dan peran serta ibu-ibu khususnya ditengah masyarakat luas dan keluarga. Program pengembangan berupa pembuatan karbol sebagai desinfektan lantai dengan cara yang sederhana. Objek pada kegiatan PPPM ini adalah ibu-ibu di Perumahan Villa Mutiara Gading yang meliputi RT.3 dan RT.4. Keadaan profil masyarakat disana sangat heterogen baik ditinjau dari segi ekonomi, sumber daya manusia, dan 
kesejahteraannya. Fokus dalam kegiatan ini adalah menumbuhkan kreativitas masyarakat untuk dapat terampil dalam membuat karbol sehingga akan tumbuh jiwa kewirausahaan bagi masyarakat. Keterampilan dalam cara pembuatan karbol ini diharapkan dapat diaplikasikan dalam kegiatan ekonomi untuk meningkatkan pendapatan warga.

\section{METODE PELAKSANAAN}

Pemecahan masalah yang ada dalam lingkungan di Perumahan Villa Mutiara Gading 3 berkaitan keberhasilan pembuatan karbol, dapat direalisasikan melalui kegiatan Pemberdayaan dan Pengabdian di Perumahan Villa Mutiara Gading 3ini berupa pembuatan karbol dengan menggunakan metode yang sederhana. Dengan adanya pembekalan cara pembuatan karbol dalam kegiatan PPPM ini, dapat memberikan keterampilan kepada warga untuk diaplikasikan. Adapun proses pembuatan karbol sebagai berikut:

a. Tahap Persiapan

Tahap ini dilakukan dengan menyiapkan alat dan bahan pembuatan karbol, diantaranya:

1) Arpus / siongka

2) $\mathrm{NaOH}$

3) Teepol

4) Champora

5) Propilenglikol

6) Aquadest

b. Tahap Pelaksanaan

1) Dibuat larutan $\mathrm{NaOH}$ dengan menambahkan $\mathrm{NaOH}$ dengan aquadest

2) Arpus dihancurkan atau digerus sampai dengan halus

3) Arpus yang telah halus dilarutkan ke dalama larutan $\mathrm{NaOH}$ sambil dipanaskan dan diaduk hingga arpus terlarut sempurna (M1)

4) Champora dilarutkan dalam pine oil hingga larut (M2)

5) M2 ditambahkan teepol campur hingga homogen, selanjutnya propilenglikol ditambahkan hingga homogen tidak terjadi pemisahan (M3)

6) M3 ditambahkan ke M2 aduk sampai dengan homogen, terakhir dimasukan ke dalam botol (kemasan), karbol siap digunakan 


\section{PEMBAHASAN}

Survei dan penjajakan dilakukan untuk mendapatkan data dan potensi wilayah dilakukan pada bulan Oktober 2018, yang selanjutnya dilakukan penetapan masalah hingga mencari solusi yang berkaitan dengan keilmuan tim pengabdian masyarakat. Kegiatan pengabdian masyarakat ini dilaksanakan pada 4 Februari 2019 di Perumahan Villa Mutiara Gading 3, Babelan, Bekasi yang mana mayoritas penduduknya adalah keluarga muda dengan anak-anak usia pra sekolah dan sekolah yang masih dalam masa pertumbuhan, sehingga dirasa perlu untuk dilakukan sosialisasi mengenai pentingnya kebersihan dan cara menjaga kebersihan rumah dengan membuat cairan desinfektan sendiri di rumah untuk mencegah penyakit yang disebarkan oleh mikroorganisme.

Pencegahan penyakit menjadi prioritas utama yaitu dengan melakukan tindakan pencegahan standar seperti menjaga kebersihan lingkungan untuk menghindari penyebaran penyakit yang disebabkan mikroorganisme. Produk antimikroba adalah zat atau campuran zat digunakan untuk menghancurkan atau menekan pertumbuhan mikroorganisme berbahaya, seperti bakteri, virus, atau jamur, yang terdapat pada benda dan permukaan benda mati (Kahrs, 1995). Produk-produk ini mengandung sekitar 275 bahan aktif berbeda dan dipasarkan dalam beberapa formulasi: semprotan, cairan pekat, bubuk, dan gas yang diaplikasikan pada permukaan yang membutuhkan pembersihan, desinfeksi, atau sterilisasi yang diklasifikasikan sesuai dengan potensinya untuk menularkan infeksi padawaktu bersentuhan (Margaret \& Quinn ScD, 2015).

Lantai adalah salah satu permukaan terpenting untuk pembentukan dan pertumbuhan mikroba karena keberadaan area dan celah yang tidak rata yang dapat menahan kelembapan (Rahma, 2015). Disinfektan adalah senjata terbaik untuk memerangi kuman.Ini adalah agen, seperti panas, radiasi, atau bahan kimia, yang menghancurkan, menetralkan atau menghambat pertumbuhan mikroorganisme (Sinha, Dasani, \& Rai, 2009). Untuk menjaga lingkungan (termasuk lantai) bebas dari mikroorganisme sepertinya mustahil karena mereka dapat dengan cepat berkembang biak. Pembersih lantai tidak akan mampu mengeluarkan mikroba sepenuhnya, tetapi penggunaan disinfektan yang sesuai akan membantu mengurangi pertumbuhan. Karena alasan lantai yang kontak langsung perlu dibersihkan secara teratur dengan disinfektan dan pembersih yang sesuai (Lalitha, Yerusha, Mutyala Rao, Sria, \& Devi., 2017).

Produk pembersih rumah tanggadisebut desinfektan karena mengandung bahan antimikroba untuk membunuh kumanpada permukaan yang terkontaminasi (Amelia, 
Kurniasih, Utami, Pijayanti, \& Suryani, 2012). Desinfektan pembersih lantai dalam ruangan tidak boleh dicampur dengan produk pembersih lain yang dapat bereaksi secara kimia menghasilkan gas beracun (Ningsih, Iravati, \& Nuryastuti, 2016). Produk desinfektan rumah tangga yang umum digunakan adalah berasal dari minyak pinus yang diperoleh dari limbah kayu yang didestilasi destruktif atau dengan distilasi dengan aliran superheated (Tinky \& Rajvinder, 2018). Untuk menghasilkan karbol minyak pinus sebagai desinfektan lantai yang berkualitas perlu dilakukan percobaan terlebih dahulu hingga didapat formula yang sesuai (Krisanti \& Suwondo, 2013). Percobaan dilakukan di laboratorium fakultas farmasi dan sains UHAMKA, hingga didapat komponen formula karbol (Tabel 1).

Tabel 1. Formula Karbol

\begin{tabular}{lc}
\hline \multicolumn{1}{c}{ Nama bahan } & Jumlah (\%) \\
\hline Arpus & 0.25 \\
Minyak pinus & 2 \\
NaOH Flake $98 \%$ & 1 \\
Propilenglikol & 2 \\
Champora & 0.5 \\
Teepol & 4 \\
Aquadest ad & 100 \\
\hline
\end{tabular}

Prosedur pembuatannya pun harus diorientasi agar arpus yang berupa bongkahan keras dapat larut dengan sempurna dan dapat bercampur dengan bahan lain. Arpus merupakan getah dari pohon pinus yang memiliki kemampuan sebagai antimikroba. Arpus tidak dapat larut dalam cairan ber $\mathrm{pH}$ netral, sehingga arpus perlu dilarutkan dalam larutan $\mathrm{NaOH}$ yang ber $\mathrm{pH}$ sangat basa yaitu 14 dengan bantuan pemanasan hingga didapat cairan kuning yang transparan. Selanjutnya champora dilarutkan dalam minyak pinus dan ditambahakan dengan teepol dan propilenglikol hingga homogen dan dicampur dengan cairan kuning transparant tadi hingga cairan menjadi coklat keruh. Karbol yang dihasilkan adalah konsentrat yang ketika akan digunakan harus diencerkan terlebih dahulu. Karbol yang dihasilkan tidak hanya dapat digunakan untuk membersihkan lantai tapi juga dapat di gunakan untuk membersihkan tempat sampah atau sumber-sumber bau lain yang dapat mengundang mikroorganisme maupun hewan penular penyakit seperti lalat. Pelatihan diikuti oleh total 35 peserta dengan gambaran demografi yang berbeda-beda. Seluruh peserta adalah ibu-ibu yang tergabung dalam grup arisan RW 3 perumahan Villa Mutiara Gading 3. 
Tabel 2. Data demografi peserta pelatihan

\begin{tabular}{clcc}
\hline Data demografi & \multicolumn{1}{c}{ Keterangan } & Jumlah & Persentasi (n=35) \\
\hline \multirow{2}{*}{ Usia } & $18-40$ tahun & 25 & $71 \%$ \\
& $40-60$ tahun & 10 & $29 \%$ \\
& SD & 0 & $0 \%$ \\
\multirow{5}{*}{ Pendidikan } & SLTP & 2 & $5.7 \%$ \\
& SLTA & 20 & $57 \%$ \\
& Pendidikan Tinggi & 13 & $37.3 \%$ \\
& PNS & 1 & $2.9 \%$ \\
& Karyawan Swasta & 7 & $20 \%$ \\
& Ibu Rumah Tangga & 28 & $77.1 \%$ \\
\hline
\end{tabular}

Peserta terbanyak masih dikalangan usia produktif (18-40 tahun). Hal ini mendukung tujuan pengmas yakni selain meningkatkan keterampilan juga dapat menjadi sumber penghasilan rumah tangga. Pada usia muda daya saing biasanya semakin tinggi. Hal ini juga didukung oleh data bahwa kebanyakan ibu-ibu yang terlibat adalah berprofesi sebagai ibu rumah tangga. Dalam hal pengurusan rumah tangga para ibu tentu dituntut untuk mengolah perbekalan rumah tangga. Karbol sendiri merupakan perbekalan rumah tangga yang tidak akan lepas dari keseharian para ibu.

Setelah selesai kegiatan pengabdian masyarakat ini diharapkan masyarakat Perumahan Mutiara Gading 3 dapat memahami arti pentingnya memelihara kebersihan, yang dapat mencegah penyakit maupun penularannya dan akan sangat berpengaruh pada tumbuh kembang anak-anak. Selain itu masyarakat diharapkan mau membuat karbol sendiri untuk memenuhi kebutuhan rumah tangga sehari - hari untuk berhemat maupun untuk meningkatkan pendapatan.

\section{KESIMPULAN}

Kegiatan PKM ini dapat berjalan lancar sesuai rencana yang telah disusun sebelumnya dan dapat meningkatkan pengetahuan dan pemahaman masyarakat perumahan Mutiara Gading 3 Babelan Bekasi tentang pembuatan Karbol dengan cara yang sederhana dan bahan yang mudah didapat.

\section{DAFTAR PUSTAKA}

Amelia, F., Kurniasih, G., Utami, N. D., Pijayanti, R. P., \& Suryani, P. S. (2012). Alternatif Desinfektan Lantai Rumah dengan Aroma Jeruk Yang Ramah Lingkungan Berbasis Senyawa Aktif yang Terkandung dalam Kecoa. Bogor.

Ariani, Setiani, O., \& Joko, T. (2015). Efektivitas Dosis Desinfektan Fenol Terhadap Angka Kuman Pada Lantai Ruang Rawat Inap Rsud Tugurejo Kota Semarang. Jurnal 
Kesehatan Masyarakat (e-Journal), 3(1), 492-500.

Brooks, G. F., Carroll, K. C., Butel, J. S., \& Morse, S. A. (2007). Medical Microbiology. 24thed. (M. Jawetz \& Adelberg's, Eds.). New York: McGraw-Hill Companies.

Dewi, D. A. P. R., Iravati, S., \& Sarto. (2016). Efektivitas Desinfektan terhadap Bakteri Ruang Bedah Intalasi Bedah Sentral (IBS) Rumah Sakit Sanglah Denpasar. ReserarchGate.

Kahrs, R. F. (1995). General Disinfection Guidelines. Rev. Sci. Tech. Off. Int. Epiz, 14(1).

Krisanti, E., \& Suwondo, A. (2013). Perbedaan Efektifitas Desinfektan Amonium Kuatener $1 \%$ dengan Fenol $1 \%$ dalam Penurunan Angka Kuman Lantai Ruang Perawatan di RSU Kardinah Kota Tegal Disinfectants in decreasing Number of Germs on the Floor in the Treatment Room at Kardinah Public Hospita. Jurnal Kesehatan LIngkungan Indonesia, 12(1).

Lalitha, N. C. ., Yerusha, C., Mutyala Rao, S., Sria, B., \& Devi., D. R. (2017). Sensitivity Of Floor Microflora Towards Various Disinfectants. World Journal Of Pharmacy And Pharmaceutical Sciences.

Listyawati, N. S. (2007). Beberapa Faktor yang Berhubungan Dengan Angka Kuman Pada Lantai Unit Perawatan Rumah Sakit Banyumanik Semarang. Semarang.

Margaret, M., \& Quinn ScD, C. (2015). Cleaning and disinfecting environmental surfaces in health care: Toward an integrated framework for infection and occupational illness prevention. American Journal of Infection Control. ELSIVIER.

Ningsih, T. A., Iravati, S., \& Nuryastuti, T. (2016). Angka kuman di ruang rawat inap RSUD Dr. M. Haulussy Ambon. Berita Kedokteran Masyarakat, 32(6), 183-188. https://doi.org/10.22146/bkm.8763

Oktarini, M. (2013). Angka dan Pola Kuman pada Dinding, Lantai dan Udara Di Ruang Icu Rsud Dr. Moewardi Surakarta. Universitas Muhammadiyah Surakarta.

Pohla, S. (2008). Sole Survivors Bacteria Build Up on Shoe Bottoms.

Rahma, E. (2015). Penentuan Koefisien Fenol Pembersih Lantai yang Mengandung Pine Oil 2,5 \% Terhadap Bakteri Pseudomonas aeruginosa. Universitas Islam Negeri Syarif Hidayatullah.

Rasmika Dewi Dap, Susi Iravati, S. (2008). Efektivitas Beberapa Desinfektan Terhadap Isolat Bakteri Lantai Ruang Bedah Instalasi Bedah Sentral (IBS) Rumah Sakit Sanglah Denpasar. Medicina, 39(2).

Sinha, A. ., Dasani, \& Rai, S. A. (2009). Germ Invasion and a Comparative Analysis of various Floor Cleaners. Electronic Journal of Biology.

Tinky, S., \& Rajvinder, S. (2018). Forensic Analysis of Newly Introduced Disinfectant Floor Cleaners by Using Thin Layer Chromatography. Austin Journal of Forensic Science and Criminology. Austin Publishing Group. 